\title{
Pengaruh Model Brain Based Learning Terhadap Pemahaman Konsep Dan Kemampuan Berpikir Kritis Fisika SMA
}

\author{
Ni Putu Devi Maretha Widyantari, Syahrial Ayub*, Jannatin 'Ardhuha \\ Pendidikan Fisika/FKIP, Universitas Mataram \\ *Email: syahrial_ayub@unram.ac.id
}

Received: 8 Oktober 2019;

Accepted: 27 Maret 2020;

Published: 30 Maret 2020

DOI: http://dx.doi.org/10.29303/jpft.v6i1.1387

\begin{abstract}
This research aims to determine (1) the influence of brain based learning (BBL) models on the understanding of physics concepts among high school students, (2) the influence of BBL models on physics critical thinking ability among high school students, and (3) the influence of BBL models on conceptual understanding and the critical thinking ability among high school students. This research is a quasi-experiment and uses non-equivalent control group design with pre-test and post-test design. The population were all students of class X MIPA of SMAN 1 Gerung in the academic year of 2018/2019. Samples were taken using purposive sampling technique. The experimental class is treated using the BBL model while the control class uses the expository learning model. The hypothesis used are the polled variance t-test and Manova test. Based on the results of the analysis, it can be concluded that (1) there are influences of BBL models on the understanding of physics concepts among high school students (2) there are influences of the BBL modesl on physics critical thinking ability among high school educators, and (3) there are influences of BBL models on conceptual understanding and critical thinking ability in physics among high school student.
\end{abstract}

Keywords: brain-based learning; concepts mastery; physics critical thinking ability

PENDAHULUAN

Ilmu Pengetahuan Alam (IPA) merupakan kumpulan pengetahuan yang berupa fakta-fakta, konsep-konsep, prinsipprinsip serta proses penemuan. IPA berkaitan dengan cara mencari tahu tentang fenomena alam secara sistematis. Pada hakikatnya sains mencakup proses, produk, dan sikap. Sains sebagai proses, lebih mengutamakan pada proses bagaimana cara memperoleh ilmu pengetahuan khususnya ilmu pengetahuan alam. Sains sebagai produk, lebih menekankan hasil yang diperoleh dalam kegiatan sains itu, baik konsep, maupun persamaan-persamaan. Sains sebagai sikap lebih menekankan pada upaya membekali, melatih, atau menanamkan nilai-nilai positif dalam diri peserta didik (Gunawan, 2015).

Fisika merupakan salah satu cabang dari IPA yang berhubungan dengan proses, sikap, dan produk ilmiah (Helmi et al. 2017).
Peserta didik dalam proses pembelajaran fisika dituntut untuk mampu memahami konsep secara menyeluruh. Pemahaman konsep yang menyeluruh merupakan syarat mutlak dalam mencapai keberhasilan pembelajaran fisika. Selain itu, fisika juga dibutuhkan untuk mempelajari fenomena alam yang menuntut kemampuan untuk berpikir sehingga perlu ditingkatkan pengetahuan akan prinsip-prinsip maupun konsep-konsep yang terdapat dalam fisika (Hapsoro, 2011).

Berdasarkan hasil observasi yang dilakukan melalui wawancara dengan salah satu guru dan beberapa peserta didik kelas $\mathrm{X}$ di SMAN 1 Gerung dikatakan bahwa proses pembelajaran yang diterapkan belum mampu meningkatkan pemahaman konsep dan kemampuan berpikir kritis peserta didik. Hal tersebut dilandasi oleh faktor minat belajar fisika yang rendah, gaya belajar peserta didik yang cenderung menghafal, 
pembelajaran

fisika

dianggap

membosankan, dan kurang tepatnya model pembelajaran yang digunakan.

Berdasarkan permasalahanpermasalahan tersebut, perlu adanya upaya dan inovasi pembelajaran fisika yang dapat membiasakan peserta didik untuk meningkatkan pemahaman terhadap suatu konsep dan mengembangkan kemampuan berpikir kritis. Upaya yang dapat dilakukan adalah dengan menerapkan model brain based learning.

Model brain-based learning adalah model yang mengadopsi teori-teori dari model pembelajaran kontekstual dan pembelajaran aktif (Purnama et al. 2015). Model brain-based learning memiliki tiga strategi utama yang dapat dikembangkan dalam proses pembelajaran diantaranya adalah menciptakan lingkungan belajar yang dapat menstimulasi kemampuan berpikir, menciptakan lingkungan belajar yang menyenangkan, dan menciptakan situasi pembelajaran aktif (Mufidah, 2014). Ketiga strategi tersebut dapat memberikan kesempatan kepada peserta didik untuk mengasah kemampuan berpikir sesuai dengan kecintaan dan kesenangan akan belajar.

Organ tubuh yang berperan penting dalam proses pembelajaran adalah otak. Given dalam Yulvinamaesari (2014) mengungkapkan otak mengembangkan lima sistem pembelajaran yang primer yaitu emosional, sosial, kognitif, fisik dan reflektif. Otak dikatakan bekerja secara optimal jika semua potensi yang dimilikinya dapat teroptimalkan dengan baik (Yulvinamaesari dan Tenriawaru, 2015).

Otak mempunyai fungsi yang berbedabeda, Mufidah (2014) mengungkapkan cara berpikir otak kiri sesuai untuk tugas teratur seperti menulis, membaca, serta simbolisme dan cara berpikir otak kanan sesuai dengan cara untuk mengetahui nonverbal seperti perasaan dan emosi, seni, kreativitas, musik, kepekaan, serta pengenalan bentuk dan pola. Lestari (2014) menyatakan jika proses pembelajaran di kelas tidak dapat melibatkan kedua fungsi otak tersebut, maka terjadi ketidakseimbangan kognitif yaitu salah satu bagian otak akan melemah yang dikarenakan salah satu bagian otak tersebut tidak digunakan. Apabila kedua belahan otak dikembangkan secara optimal dan seimbang, maka belajar dapat berjalan secara maksimal. Untuk itu diperlukan adanya upaya untuk menyeimbangkan otak kanan dan otak kiri, salah satu caranya adalah dengan mendengarkan musik.

Mendengarkan musik merupakan salah satu cara untuk merangsang pikiran, sehingga peserta didik dapat menerima materi pembelajaran dengan baik. Musik dapat digunakan untuk media pembelajaran karena musik mampu menyeimbangkan antara otak kanan dengan otak kiri, ini berarti menyeimbangkan antara aspek intelektual dengan aspek emosional.

Efek penggunaan musik terhadap pikiran dan tubuh adalah untuk meningkatkan energi otot, mempengaruhi detak jantung, mengurangi stress, menghilangkan kelelahan, membantu melegakan emosi, merangsang kreativitas, sensitivitas, dan berpikir. Hal ini dapat diterapkan dalam pembelajaran karena musik dapat meningkatkan kemampuan belajar secara menyenangkan (Jensen, 2011).

Pemilihan musik yang tepat menjadi bagian yang penting dalam pembelajaran, dikarenakan setiap jenis musik memiliki fungsi yang berbeda-beda. Jensen (2011) mengungkapkan beberapa pilihan musik yang bermanfaat untuk pembelajaran yaitu musik klasik dan romantik dapat digunakan untuk membangun fantasi, membangun emosi, menyampaikan cerita dan menyampaikan materi. Musik yang lembut 
dapat digunakan untuk meningkatkan fokus penulisan, sedangkan untuk membuat peserta didik menjadi rileks dapat digunakan musik dengan suara alam dan musik piano.

Tahap model brain-based learning terdiri dari tujuh tahap yang dijabarkan oleh Jensen (2011) yaitu pra-pemaparan, persiapan, inisiasi dan akuisisi, elaborasi, inkubasi dan pengaturan memori, verifikasi atau pengecekan, selebrasi dan integrasi.

Tahap inkubasi merupakan tahap tidak adanya kegiatan. Pada tahap ini peserta didik diberikan waktu untuk istirahat disela-sela proses pembelajaran dengan diiringi musik. Musik bermanfaat untuk menyeimbangkan potensi otak kanan dan potensi otak kiri. Menurut Jensen (2011) lamanya waktu untuk istirahat sekitar 5-10 menit.

Penelitian mengenai pemahaman konsep dan kemampuan berpikir kritis dirasa penting karena merupakan modal bagi peserta didik untuk dapat mengembangkan pengetahuannya secara luas.

Pemahaman merupakan kemampuan menangkap makna dari suatu konsep yang memerlukan hubungan antar konsep dengan makna yang ada dalam konsep tersebut (Sudjana dalam Sahara, 2015). Pemahaman konsep didefinisikan sebagai kemampuan peserta didik dalam memahami suatu abstraksi yang menggambarkan karakteristik konsep secara ilmiah, baik secara teori maupun penerapannya dalam kehidupan sehari-hari (Riyadi et al. 2015). Menurut Anderson \& Krathwohl (2014) peserta didik dikatakan memahami bila mereka dapat mengkonstruksi makna dari pesan-pesan pembelajaran, baik yang bersifat lisan, tulisan ataupun grafis, yang disampaikan melalui pengajaran, buku, atau layar komputer. Indikator memahami terbagi menjadi tujuh bagian yaitu menafsirkan, mencontohkan, mengklasifikasikan, merangkum, menyimpulkan, membandingkan, dan menjelaskan.
Keberhasilan seseorang dalam menjalani berbagai aktifitasnya dalam kehidupan sehari-hari dapat ditentukan oleh kemampuannya dalam berpikir. Proses berpikir merupakan suatu pengalaman memproses persoalan untuk mendapatkan dan menentukan suatu gagasan yang baru sebagai jawaban dari persoalan yang dihadapi. Terdapat beberapa jenis kemampuan berpikir, salah satu diantaranya adalah kemampuan berpikir kritis. Latifa et al. (2017) mengungkapkan bahwa kemampuan berpikir kritis merupakan proses dan kemampuan yang dilibatkan dalam membuat keputusan secara rasional. Handriani et al. (2015) mengungkapkan bahwa kemampuan berpikir kritis adalah suatu proses kognisi peserta didik secara mendalam yang diterapkan dalam kegiatan pembelajaran.

Kemampuan berpikir kritis yang dikembangkan oleh Facione (2011) terbagi menjadi enam indikator yaitu interpretasi, analisis, inferensi, menjelaskan, evaluasi, dan regulasi diri.

\section{METODE PENELITIAN}

Penelitian ini termasuk penelitian kuasi eksperimen dengan desain nonequivalent control group design with pretest and post-test. Populasi penelitian ini adalah seluruh peserta didik kelas X MIPA SMAN 1 Gerung tahun pelajaran 2018/2019 dengan teknik pengambilan sampel menggunakan purposive sampling, sehingga diperoleh $\mathrm{X}$ MIPA 1 sebagai kelas eksperimen dan X MIPA 2 sebagai kelas kontrol.

Indikator pemahaman konsep yang digunakan pada penelitian ini ada tujuh bagian yaitu menafsirkan, mencontohkan, mengklasifikasikan, merangkum, menyimpulkan, membandingkan, dan menjelaskan. Sedangkan, indikator kemampuan berpikir kritis yang digunakan 
pada penelitian ini ada lima yaitu interpretasi, analisis, inferensi, menjelaskan, evaluasi.

Instrumen yang digunakan untuk mengukur pemahaman konsep adalah tes pilihan ganda sebanyak 17 soal dan instrumen yang digunakan untuk mengukur kemampuan berpikir kritis adalah tes uraian sebanyak 5 soal, di mana soal-soal tersebut telah diuji validitas, reliabilitas, tingkat kesukaran soal, dan daya beda soal. Data pemahaman konsep dan kemampuan berpikir kritis peserta didik yang diperoleh kemudian diklasifikasi berdasarkan pedoman kategori masing-masing seperti pada Tabel 1 dan Tabel 2 berikut.

Tabel 1. Kriteria Tingkat Pemahaman Konsep

\begin{tabular}{lll}
\hline No. & Klasifikasi & Interpretasi \\
\hline 1 & $85,00-100$ & Sangat Tinggi \\
2 & $70,00-84,99$ & Tinggi \\
3 & $55,00-69,99$ & Sedang \\
4 & $40,00-54,99$ & Rendah \\
5 & $0,00-39,99$ & Sangat Rendah \\
\hline
\end{tabular}

(Ningsih dalam Mawaddah et al. 2016)

Tabel 2. Kriteria Kemampuan Berpikir Kritis

\begin{tabular}{lcl}
\hline No. & Klasifikasi & Interpretasi \\
\hline 1 & $81,25<x \leq 100$ & Sangat Tinggi \\
2 & $71,50<x \leq 81,25$ & Tinggi \\
3 & $62,50<x \leq 71,50$ & Sedang \\
4 & $43,75<x \leq 62,50$ & Rendah \\
5 & $0,00<x \leq 43,75$ & Sangat Rendah \\
\hline
\end{tabular}

(Ermayanti dan Sulisworo, 2016)

Hipotesis pada penelitian ini ada tiga yaitu (1) Apakah terdapat pengaruh model brain-based learning terhadap pemahaman konsep fisika peserta didik SMA? (2) Apakah terdapat pengaruh model brainbased learning terhadap kemampuan berpikir kritis fisika peserta didik SMA? dan (3) Apakah terdapat pengaruh model brainbased learning terhadap pemahaman konsep dan kemampuan berpikir kritis fisika peserta didik SMA?

Hipotesis pertama dan kedua diolah menggunakan uji statistik parametrik dengan uji-t polled varians dan hipotesis ketiga diolah menggunakan uji analisis variansi multivariat (MANOVA) menggunakan bantuan program IBM SPSS 23 dengan taraf signifikan 5\%.

\section{HASIL DAN PEMBAHASAN}

Berdasarkan nilai rata-rata tes awal (pre-test) pemahaman konsep peserta didik pada kedua kelas berkategori sangat rendah yaitu kelas eksperimen sebesar 38,23 dan kelas kontrol sebesar 34,11.

Hasil dari tes akhir (post-test) pemahaman konsep peserta didik pada kedua kelas yakni kelas eksperimen dan kelas kontrol diperoleh nilai rata-rata pemahaman konsep sebesar 80,06 dan 71,76. Berdasarkan kriteria pemahaman konsep, nilai rata-rata peserta didik dari kelas eksperimen dan kelas kontrol samasama berkategori tinggi. Meskipun kedua kelas memiliki nilai rata-rata tes akhir yang sama-sama berkategori tinggi, namun, nilai rata-rata kelas eksperimen lebih tinggi dibandingkan dengan nilai rata-rata pada kelas kontrol.

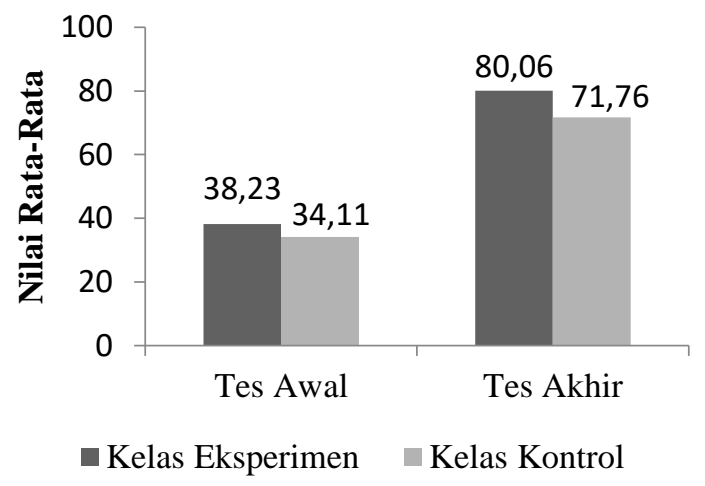

Gambar 1. Perbandingan nilai rata-rata tes awal dan tes akhir pemahaman konsep.

Nilai rata-rata pada setiap indikator pemahaman konsep menunjukkan bahwa nilai rata-rata peserta didik pada kelas eksperimen lebih tinggi dibandingkan dengan kelas kontrol pada setiap indikatornya.

Nilai rata-rata pemahaman konsep tertinggi pada kelas eksperimen dan kelas kontrol sama-sama berada pada indikator 
menjelaskan dengan nilai 89,28 yang termasuk kategori sangat tinggi pada kelas eksperimen dan 82,00 yang termasuk kategori tinggi untuk kelas kontrol.

Nilai rata-rata pemahaman konsep terendah untuk peserta didik pada kelas eksperimen dan kelas kontrol juga berada pada indikator yang sama yaitu indikator menyimpulkan dengan perolehan nilai 67,85 yang termasuk kategori sedang untuk kelas eksperimen dan 58,00 yang juga berkategori sedang untuk kelas kontrol.

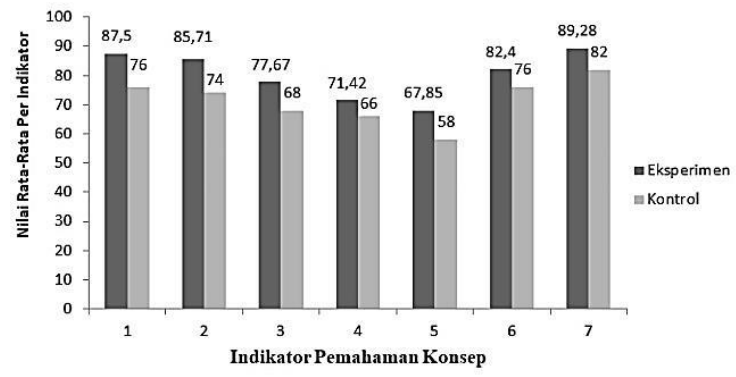

Gambar 2. Nilai rata-rata pemahaman konsep per indikator yaitu 1. menafsirkan, 2. mencontohkan, 3 . mengklasifikasi, 4. merangkum, 5. menyimpulkan,

6. membandingkan, 7. menjelaskan.

Peneliti menduga nilai tertinggi pada indikator menjelaskan disebabkan peserta didik di kedua kelas sudah sangat mampu untuk memilih jawaban yang tepat. Kemampuan peserta didik dalam memilih jawaban yang tepat dikarenakan pemahaman konsep yang dimiliki sudah sangat tinggi pada indikator menjelaskan. Sedangkan, nilai terendah untuk kedua kelas pada indikator menyimpulkan dapat disebabkan oleh pemahaman konsep yang masih berkategori sedang untuk membuat kesimpulan dari soal-soal dalam bentuk grafik baik di kelas eksperimen maupun di kelas kontrol.

Berdasarkan uji hipotesis terhadap data pemahaman konsep peserta didik pada kelas eksperimen dan kelas kontrol dengan menggunakan uji-t polled varians diperoleh nilai $t_{\text {hitung }} 2,1957$ dengan nilai $t_{\text {tabel }} 2,0095$ yang menunjukkan $\left(\mathrm{Ha}_{1}\right)$ diterima yaitu terdapat pangaruh model brain based learning terhadap pemahaman konsep fisika peserta didik SMA. Hasil penelitian ini memiliki kesesuaian dengan penelitian Husein (2015) terkait model brain based learning yang mengungkapkan bahwa terdapat pengaruh pendekatan brain based learning terhadap pemahaman konsep peserta didik.

Nilai rata-rata tes awal (pre-test) kemampuan berpikir kritis kedua kelas berkategori sangat rendah yaitu kelas eksperimen sebesar 31,96 dan kelas kontrol sebesar 29,20.

Peserta didik pada kelas eksperimen yang diberikan perlakuan berupa model brain-based learning memiliki nilai rata-rata tes akhir kemampuan berpikir kritis sebesar 78,21 yang berkategori tinggi. Sedangkan, peserta didik pada kelas kontrol yang diberikan perlakuan berupa model pembelajaran ekspositori memiliki nilai rata-rata tes akhir kemampuan berpikir kritis sebesar 69,60 yang termasuk ke dalam kategori sedang.

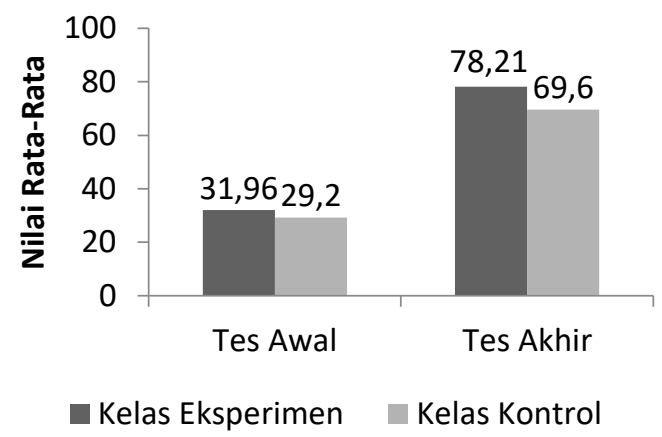

Gambar 3. Perbandingan nilai rata-rata tes awal dan tes akhir kemampuan berpikir kritis.

Jika dilihat nilai rata-rata kemampuan berpikir kritis untuk kedua kelas pada setiap indikator, peserta didik pada kelas eksperimen memiliki nilai rata-rata lebih tinggi dibandingkan dengan peserta didik pada kelas kontrol untuk setiap indikatornya.

Nilai rata-rata kemampuan berpikir kritis tertinggi untuk kelas eksperimen adalah pada indikator menjelaskan dengan perolehan nilai 91,07 yang termasuk 
kategori sangat tinggi. Sedangkan, untuk kelas kontrol nilai tertinggi berada pada indikator analisis dengan perolehan nilai 79,00 yang termasuk kategori tinggi. Nilai rata-rata terendah peserta didik untuk kelas eksperimen dan kelas kontrol berada pada indikator yang sama yaitu indikator evaluasi dengan perolehan nilai 52,67 yang termasuk kategori rendah untuk kelas eksperimen dan 49,00 yang juga termasuk kategori rendah untuk kelas kontrol.

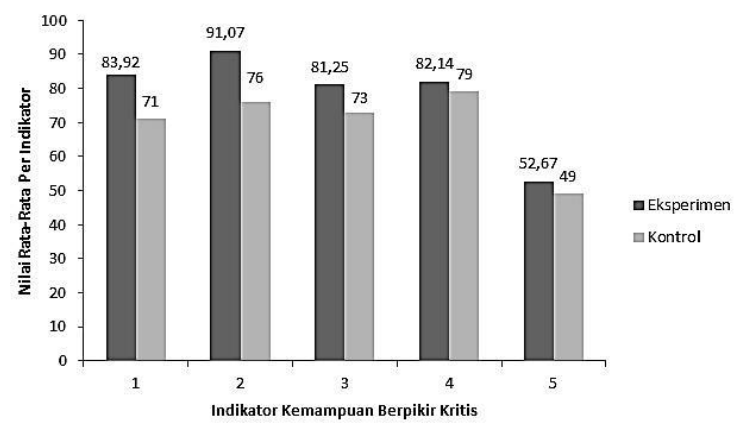

Gambar 4. Nilai rata-rata kemampuan berpikir kritis per indikator. yaitu 1. interpretasi, 2. menjelaskan, 3. inferensi, 4. analisis, 5. evaluasi.

Nilai tertinggi peserta didik pada kelas eksperimen untuk indikator menjelaskan disebabkan peserta didik sudah mampu menggunakan kemampuan berpikir kritisnya untuk menjelaskan suatu kejadian disertai dengan alasan yang tepat. Sedangkan, pada kelas kontrol, peserta didik juga sudah mampu menjelaskan suatu kejadian namun alasan yang diberikan untuk menjelaskan kejadian tersebut kurang tepat.

Nilai tertinggi peserta didik pada kelas kontrol berada pada indikator analisis. Peneliti menduga peserta didik pada kelas kontrol lebih menggunakan kemampuan berpikir kritisnya untuk mengerjakan soal dalam bentuk matematis daripada dalam bentuk penjelasan yang disertai alasan. Meskipun nilai tertinggi peserta didik pada kelas kontrol berada pada indikator analisis, namun nilai yang diperoleh lebih kecil dibandingkan nilai kelas eksperimen pada indikator analisis.
Nilai terendah peserta didik pada kedua kelas berada pada indikator evaluasi. Hal ini dikarenakan peserta didik pada kedua kelas belum cukup mampu menggunakan kemampuan berpikir kritisnya untuk memilih pernyataan yang tepat beserta menguji kebenaran pernyataan yang dipilih secara matematis.

Berdasarkan uji hipotesis menggunakan uji-t polled varians diperoleh nilai $t_{\text {hitung }} 3,43$ dengan nilai $t_{\text {tabel }} 2,0095$ yang menunjukkan $\left(\mathrm{Ha}_{2}\right)$ diterima yaitu terdapat pangaruh model brain-based learning terhadap kemampuan berpikir kritis fisika peserta didik SMA.

Hasil penelitian ini memiliki kesesuaian dengan penelitian sebelumnya terkait model brain based learning diantaranya Lestari (2014) yang mengungkapkan terdapat peningkatan kemampuan berpikir kritis dan respon positif peserta didik dalam mengerjakan tes diiringi dengan musik, Nahdi mengungkapkan bahwa terjadi peningkatan kemampuan berpikir kritis peserta didik melalui model brain based learning, dan Herliandry et al. (2019) menyimpulkan bahwa terdapat pengaruh model brain based learning terhadap kemampuan berpikir krtis peserta didik.

Manova merupakan metode statistik yang memungkinkan peneliti dapat menguji dua atau lebih variabel terikat secara bersamaan (Stevens dalam Warne, 2014:2). Uji Manova digunakan untuk mengetahui ada atau tidaknya pengaruh penerapan model brain based learning terhadap pemahaman konsep dan kemampuan berpikir kritis fisika peserta didik secara simultan.

Berdasarkan hasil uji Manova dengan bantuan IBM SPSS 23 diperoleh hasil uji Roy's Largest Root menghasilkan taraf signifikan sebesar 0,002 yang berarti nilai ini lebih kecil dari pada nilai signifikan 0,05. 
Hal ini menunjukkan bahwa $\left(\mathrm{Ha}_{3}\right)$ diterima yang artinya terdapat pengaruh model brain based learning terhadap pemahaman konsep dan kemampuan berpikir kritis fisika peserta didik secara simultan.

Pengaruh perlakuan yang diberikan pada kelas eksperimen yang menerapkan model brain based learning dan kelas kontrol yang menerapkan model pembelajaran ekspositori sama-sama memberikan pengaruh terhadap pemahaman konsep dan kemampuan berpikir kritis peserta didik. Tingkat pemahaman konsep dan kemampuan berpikir kritis pada kelas eksperimen yang menerapkan model brain based learning mengalami peningkatan yang lebih tinggi jika dibandingkan dengan kelas kontrol yang menerapkan model pembelajaran ekspositori jika dilihat dari nilai pre-test dan post-test. Perbedaan tersebut tidak terjadi secara kebetulan, melainkan karena adanya perbedaan pada tahap-tahap pembelajaran antara kedua kelas tersebut.

Brain based learning adalah pembelajaran yang mengadopsi teori-teori dari pembelajaran kontekstual dan pembelajaran aktif (Purnama et al. 2015). Keunggulan dari model ini yaitu menekankan pada kesenangan dan kecintaan akan belajar sehingga peserta didik akan lebih mudah memahami materi yang disampaikan (Lestari, 2014). Selain itu, tahapan pembelajaran pada model brain based learning menunjang dalam peningkatan pemahaman konsep dan pengembangan kemampuan berpikir kritis peserta didik.

Pemberian tes secara individu pada tahap verifikasi memiliki dampak yang baik dalam proses pembelajaran. Sebelum pemberian tes secara individu, peserta didik aktif bertanya terkait materi yang disampaikan maupun pada saat diskusi kelompok. Aktifnya peserta didik di dalam kelas membuat peserta didik lebih memahami materi yang diajarkan.

Tahap inkubasi atau pengaturan memori merupakan tahap dimana peserta didik diberikan waktu untuk istirahat yaitu waktu di mana tidak ada kegiatan belajar dan diiringi dengan pemutaran musik. Musik disini berfungsi sebagai penyeimbang otak kanan. Pada proses pembelajaran, penggunaan potensi otak kiri lebih dominan dibandingkan dengan penggunaan potensi otak kanan, sehingga untuk menyeimbangkan potensi otak kiri dan otak kanan peserta didik diberikan waktu untuk istirahat disela-sela proses pembelajaran dan diiringi dengan pemutaram musik.

Berdasarkan pengamatan peneliti pada saat pemutaran musik, terdapat beberapa peserta didik yang masih menulis dan berbicara dengan teman sebangku. Meskipun demikian, sebagian besar peserta didik menikmati musik yang diputarkan dan tidak mengerjakan apapun serta memberikan respon yang baik yaitu peserta didik menjadi lebih semangat dan menjadi lebih rileks mengikuti proses pembelajaran selanjutnya.

Penerapan model brain based learning memberikan kesempatan kepada peserta didik belajar dengan suasana hati yang baik. Selain itu, penggunaan musik pada proses pembelajaran menjadikan pembelajaran fisika tidak membosankan meskipun proses pembelajaran fisika berlangsung selama (3x45 menit) pelajaran dikarenakan peserta didik merasa tenang dan rileks berada di dalam kelas serta penggunaan musik pada proses pembelajaran fisika dapat membuang stigma bahwa pembelajaran fisika membosankan dan menakutkan menjadi pembelajaran fisika yang menyenangkan. Hal ini memiliki kesesuaian dengan hasil penelitian Linda dalam Prakoso et al. (2017) yang mengungkapkan bahwa penggunaan musik dalam pembelajaran akan mampu membuat peserta didik menjadi lebih 
bersemangat untuk belajar dan mampu merangsang otak untuk bekerja. Selain itu, hasil penelitian Herliandry et al. (2019) juga mengungkapkan bahwa pembelajaran dengan menggunakan musik melalui model brain based learning membuat peserta didik menjadi lebih semangat dan ceria.

Peneliti menduga proses pembelajaran pada kelas kontrol yang menerapkan model pembelajaran ekspositori kurang optimal diterapkan dikarenakan beberapa faktor diantaranya pembelajaran kurang menarik, peserta didik kurang aktif bertanya, pengetahuan yang dimiliki peserta didik sebatas apa yang disampaikan oleh guru, peserta didik menjadi cepat bosan belajar fisika dikarenakan jam pelajaran fisika yang cukup lama yaitu (3x45 menit) pelajaran dengan proses pembelajaran yang cenderung ceramah dan pemberian tugas, sehingga peserta didik menjadi kurang aktif dan berakibat pada kurangnya peningkatan pemahaman konsep dan pengembangan kemampuan berpikir kritis fisika peserta didik. Hal ini memiliki kesesuaian dengan apa yang diungkapkan oleh Prakoso et al. (2017) yang menyatakan bahwa pembelajaran yang membosankan menyebabkan peserta didik kurang termotivasi sehingga dapat menimbulkan kurangnya pemahaman konsep dan kemampuan berpikir kritis fisika peserta didik.

Berdasarkan hasil penelitian dan uji hipotesis yang telah dilakukan, peneliti dapat mengatakan bahwa peningkatan kemampuan berpikir kritis yang dialami peserta didik akan sejalan dengan peningkatan pemahaman konsep peserta didik. Hal tersebut memiliki kesesuaian dengan hasil penelitian Sari et al. (2016) yang mengungkapkan bahwa kemampuan berpikir kritis memiliki hubungan dengan pemahaman konsep, dimana ketika kemampuan berpikir kritis peserta didik meningkat, maka pemahaman konsep peserta didik juga akan meningkat. Hal ini menunjukkan bahwa kemampuan berpikir kritis merupakan salah satu faktor yang dapat meningkatkan pemahaman konsep peserta didik.

\section{PENUTUP}

Berdasarkan hasil penelitian dan pembahasan, maka dapat disimpulkan bahwa (1) terdapat pengaruh model brainbased learning terhadap pemahaman konsep fisika peserta didik SMA, (2) terdapat pengaruh model brain-based learning terhadap kemampuan berpikir kritis fisika peserta didik SMA, dan (3) terdapat pengaruh model brain-based learning terhadap pemahaman konsep dan kemampuan berpikir kritis fisika peserta didik SMA.

\section{REFERENSI}

Anderson \& Krathwohl. (2014). Kerangka Landasan untuk Pembelajaran, Pengajaran, dan Asesmen. Yogyakarta: Pustaka Pelajar.

Ermayanti., \& Sulisworo, D. (2016). Tingkat Kemampuan Berpikir Kritis Peserta Didik setelah Penerapan Model Pembelajaran Student Team Achievement Divisions (STAN) pada Siswa Sekolah Menengah Atas (SMA). Prosiding Seminar Nasional Quntum :175-181.

Facione, P. A. (2011). Critical Thinking: What It Is and Why It Counts. Insight Assessement. -: 1-28.

Gunawan. (2015). Model Pembelajaran Sains Berbasis ICT. Mataram: FKIP UNRAM.

Handriani, L. S., Harjono, A., \& Doyan, A. (2015). Pengaruh Model Pembelajaran Inkuiri Terstruktur dengan Pendekatan Saintifik Terhadap Kemampuan Berpikir Kritis Dan Hasil Belajar 
Fisika Siswa. Jurnal Pendidikan Fisika dan Teknologi. 1(3): 212-220.

Hapsoro, C.A., \& Susanto, H. (2011). Penerapan Pembelajaran Problem Based Instruction Berbantuan Alat Peraga pada Materi Cahaya di SMP. Jurnal Pendidikan Fisika Indonesia. 7(1): 29-32.

Helmi, F., Rokhmat, J., \& 'Ardhuha, J. (2017). Pengaruh Pendekatan Berpikir Kausalitik Ber-Scaffolding Tipe 2B Termodifikasi Berbantuan LKS Terhadap Kemampuan Pemecahan Masalah Fluida Dinamis Siswa. Jurnal Pendidikan Fisika dan Teknologi. 3(1): 68-75.

Herliandry, L. D., Harjono, A., \& 'Ardhuha, J. (2019). Kemampuan Berpikir Kritis Fisika Peserta Didik Kelas X dengan Model Brain Based Learning. Jurnal Penelitian Pendidikan IPA (JPPIPA). 5(1): 39-47.

Husein, N. A. (2015). Pengaruh Pendekatan Brain Based Learning Terhadap Kemampuan Pemahaman Konsep Matematika Siswa. Skripsi. FKIP, Pend. Matematika, Universitas Islam Negeri Syarif Hidayatullah. Jakarta.

Jensen, E. (2011). Pembelajaran Berbasis Otak Edisi Kedua. Jakarta Barat. Ideks.

Latifa, B. R. A., Verawati, N. N. S. P., \& Harjono, A. (2017). Pengaruh Model Learning Cycle 5e (Engage, Explore, Explain, Elaboration, \& Evaluate) Terhadap Kemampuan Berpikir Kritis Peserta Didik Kelas X MAN 1 Mataram. Jurnal Pendidikan Fisika dan Teknologi. 3(1): 61-67.

Lestari, K. E. (2014). Implementasi Brain Based Learning Untuk Meningkatkan Kemampuan Koneksi dan Kemampuan Berpikir Kritis Serta Motivasi Belajar Siswa SMP. Jurnal Pendidikan Unsika. 2(1): 36-46.

Mawaddah, S., \& Maryanti, R. (2016). Kemampuan Pemahaman Konsep Matematis Siswa SMP dalam Pembelajaran Menggunakan Model
Penemuan Terbimbing (Discovery Learning). Jurnal Pendidikan Matematika. 4(1): 76-85.

Mufidah, L. L. N. (2014). Brain Based Learning and Teaching. Yogyakarta: Teras.

Nahdi, D. S., (2015). Meningkatkan Kemampuan Berpikir Kritis dan Penalaran Matematis Siswa Melalui Model Brain Based Learning. Jurnal Cakrawala Pendas. 1(1): 13-22.

Prakoso, Y. A., Hannifah., \& Maizora, S. (2017). Pengaruh Musik Klasik Terhadap Hasil dan Aktivitas Belajar Matematika Siswa Kelas VII di SMPN 2 Kota Bengkulu. Jurnal Penelitian Pembelajaran Matematika Sekolah. 1(1): 26-35.

Purnama, R., Ratman, R., \& Solfarina, S. (2015). Pengaruh Mind Mapping Melalui Brain Based Learning Terhadap Hasil Belajar Siswa Pada Materi Ikatan Kimia Di Kelas X MIA SMA Negeri 1 Marawola. Jurnal Akademika Kimia, 4(3), 149-154.

Riyadi, A., Gunawan, G., \& Ardhuha, J. (2015). Pengaruh Penerapan Model Pembelajaran Kontekstual Berbantuan Media Flash Terhadap Pemahaman Konsep Fisika Siswa. Jurnal Pendidikan Fisika dan Teknologi, 1(2), 87-91.

Sahara, L. (2015). Penerapan Model Concept Teaching Pendekatan Concept Attainment untuk Meningkatkan Pemahaman Konsep Ipa Fisika Siswa Kelas Viiil Smp Negeri 5 Kendari pada Materi Pokok Usaha dan Energi. Jurnal Pendidikan Fisika dan Teknologi, 1(2), 108-112.

Sari, A. L. R., \& Parno \& Taufiq, A. (2016). Kemampuan Berpikir Kritis dan Pemahaman Konsep Fisika Siswa SMA pada Materi Hukum Newton. In Prosiding Seminar Nasional Pend. IPA Pascasarjana Universitas Negeri Malang. 
Warne, R.T. (2014). A Primer on Multivariate Analysis of Variance (MANOVA) for Behavior Scientist. Practical Assesment, Research \& Evaluation 19(17):1-10.

Yulvinamaesari. (2014). Implementasi Brain Based Learning dalam Pembelajaran Berbasis Pendidikan Karakter. Prosiding Seminar Nasional. 1(1): 100-106.

Yulvinamaesari \& Tenriawaru, E. P. (2015). Efektifitas Model Brain Based Learning Terhadap Kemampuan Multiple Intelligence pada Mahasiswa Fisika Universitas Cokroaminoto Palopo. Jurnal Dinamika. 6 (2): 58-81. 